\title{
CONCENTRATION OF RADIOCARBON AND ITS CHEMICAL FORMS IN GASEOUS EFFLUENTS, ENVIRONMENTAL AIR, NUCLEAR WASTE AND PRIMARY WATER OF A PRESSURIZED WATER REACTOR POWER PLANT IN HUNGARY
}

\author{
MIHÁLY VERES, ${ }^{1}$ EDE HERTELENDI, ${ }^{1}$ GYÖRGY UCHRIN, ${ }^{2}$ ESZTER CSABA, ${ }^{2}$ \\ ISTVÁN BARNABÁS, ${ }^{3}$ PETTER ORMAI, ${ }^{3}$ GÁBOR VOLENT ${ }^{3}$ and ISTVÁN FUTÓ ${ }^{1}$
}

\begin{abstract}
We measured airborne releases of ${ }^{14} \mathrm{C}$ from the Paks Pressurized Water Reactor (PWR) Nuclear Power Plant (NPP).Two continuous stack samplers collect ${ }^{14} \mathrm{C}$ in ${ }^{14} \mathrm{CO}_{2}$ and ${ }^{14} \mathrm{C}_{\mathrm{n}} \mathrm{H}_{\mathrm{m}}$ chemical forms. ${ }^{14} \mathrm{C}$ activities were measured using two techniques; environmental air samples of lower activities were analyzed by proportional counting, stack samples were measured by liquid scintillation counting. ${ }^{14} \mathrm{C}$ concentration of air in the stack varies between 80 and $200 \mathrm{Bqm}^{-3}$. The average normalized yearly discharge rates for $1988-1993$ were $0.74 \mathrm{TBqGW}_{\mathrm{e}}^{-1} \mathrm{y}^{-1}$ for hydrocarbons and $0.06 \mathrm{TBqGW}_{\mathrm{e}}^{-1} \mathrm{y}^{-1}$ for $\mathrm{CO}_{2}$. The discharge rate from Paks Nuclear Power Plant is about four times higher than the mean discharge value of a typical Western European PWR NPP. The higher ${ }^{14} \mathrm{C}$ production may be apportioned to the higher level of nitrogen impurities in the primary coolant. Monitoring the long-term average excess from the NPP gave $\mathrm{D}^{14} \mathrm{C}=3.5 \%$ for $\mathrm{CO}_{2}$ and $\mathrm{D}^{14} \mathrm{C}=20 \% 0$ for hydrocarbons. We determined ${ }^{14} \mathrm{C}$ activity concentration in the primary coolant to be ca. $4 \mathrm{kBq}$ liter ${ }^{-1}$. The ${ }^{14} \mathrm{C}$ activity concentrations of spent mixed bed ion exchange resins vary between 1.2 and $5.3 \mathrm{MBqkg}^{-1}$ dry weight.
\end{abstract}

\section{INTRODUCTION}

Radiocarbon is produced in light water reactors by neutron activation of oxides in the fuel, moderators and coolant $\left[{ }^{17} \mathrm{O}(\mathrm{n}, \alpha){ }^{14} \mathrm{C}\right.$ reaction] and by the ${ }^{14} \mathrm{~N}(\mathrm{n}, \mathrm{p}){ }^{14} \mathrm{C}$ reaction for impurities in the fuel, moderator and coolant (Davis 1979). The mean values of ${ }^{14} \mathrm{C}$ production rates for pressurized water reactors (PWRs) are $0.57 \mathrm{TBqGW}_{\mathrm{e}}^{-1} \mathrm{y}^{-1}, 0.97 \mathrm{TBqGW}_{\mathrm{e}}^{-1} \mathrm{y}^{-1}$, and $0.19 \mathrm{TBqGW}_{\mathrm{e}}^{-1} \mathrm{y}^{-1}$ in fuel, structural materials and coolant, respectively, when a concentration of $5 \mathrm{ppm}$ nitrogen is assumed in the coolant (Kunz 1985). The ${ }^{14} \mathrm{C}$ that is produced in the coolant will be released to the environment mainly via the stack; the ${ }^{14} \mathrm{C}$ discharged with liquid and solid wastes is $<5 \%$ of the gaseous discharge.

Otlet, Fulker and Walker (1992) summarized the environmental impact of the nuclear industry. Several publications discuss various aspects of ${ }^{14} \mathrm{C}$ production rates of nuclear installations (Hertelendi, Uchrin and Ormai 1989; Loosli and Oeschger, 1989; McCartney et al. 1986; Obelić et al. 1986; Otlet, Walker and Longely 1983; Otlet, Walker and Fuller 1990; Otlet, Longley and Walker 1989; Povinec, Chudý and Šivo 1986; Stenström et al. 1993a, 1993b, 1995). Uchrin et al. (1992) compiled ${ }^{14} \mathrm{C}$ release data for PWR-type nuclear power plants (NPPs). The dominant chemical forms of radiocarbon are hydrocarbons and, to a lesser degree, carbon dioxide. Rublevszkij's (1987) calculations give a range of $0.95-10.6 \mathrm{TBqGW}_{\mathrm{e}}^{-1} \mathrm{y}^{-1}$ for the production rate of ${ }^{14} \mathrm{C}$ in the water-water energetic reactor, WWER-440 (one of the USSR PWR-type NPPs). One possible explanation for these high discharge values compared to the Western European PWRs' average discharge volume, 0.22 $\mathrm{TBqGW}_{\mathrm{e}}{ }^{-1} \mathrm{y}^{-1}$ (UNSCEAR 1982) is the use of nitrogen gas for pressurization and chemicals with nitrogen content (e.g., ammonium hydroxide and hydrazine) in the primary coolant (Rublevszkij 1987). Outside of these data only a few operational results are available on discharges of Soviet-type PWRs. One exception is a report from Finland (Snellman 1989). ${ }^{4}$

\footnotetext{
${ }^{1}$ Institute of Nuclear Research of the Hungarian Academy of Sciences, P.O. Box 51, H-4001 Debrecen, Hungary

${ }^{2}$ Institute of Isotopes of the Hungarian Academy of Sciences, P.O. Box 77, H-1525 Budapest, Hungary

${ }^{3}$ Paks Nuclear Power Plant, P.O. Box 71, H-7031 Paks, Hungary

${ }^{4}$ The total ${ }^{14} \mathrm{C}$ gaseous release at Loviisa I. NPP (Finland), which uses a similar type of reactor to the Paks NPP, is 0.390 $\mathrm{TBqGW}_{\mathrm{e}}^{-1} \mathbf{y}^{-1}$.
} 
The Hungarian NPP at Paks, which also uses Soviet-design PWRs, consists of four power units of $440 \mathrm{MWe}$ capacity each. A program was begun in 1988 to determine the ${ }^{14} \mathrm{C}$ discharge of the Paks NPP. The objectives of the program were: 1 ) to develop and run a reliable sampling system for measuring ${ }^{14} \mathrm{C}$ in various chemical forms on a routine basis in the stack and in the environment of the $\mathrm{NPP} ; 2$ ) to determine the annual emission of ${ }^{14} \mathrm{C}$ through various release pathways; and 3) to follow the local impact of the ${ }^{14} \mathrm{C}$ release.

\section{METHODS}

We developed a differential ${ }^{14} \mathrm{C}$ sampler to obtain integrated samples for measuring ${ }^{14} \mathrm{C}$ in chemical forms such as $\mathrm{CO}_{2}, \mathrm{CH}_{4}$ and other hydrocarbons. Atmospheric $\mathrm{CO}_{2}$ served as a carrier gas to avoid difficulties that might originate from the minute amount of the sample to be collected in the case of hydrocarbons. ${ }^{14} \mathrm{C}$ is collected in the form of $\mathrm{CO}_{2}$ for all chemical species because hydrocarbons are oxidized by a palladium catalyst kept at $600^{\circ} \mathrm{C}$. The $\mathrm{CO}_{2}$ that is present or being formed is then absorbed in trapping columns filled with $3 \mathrm{M} \mathrm{NaOH}$ solution.

We measured the activity of the samples using two methods. Samples of lower activities were analyzed using the proportional counting method (Hertelendi et al. 1989). To extract the $\mathrm{CO}_{2}$ from the samples, concentrated sulphuric acid was added to the $\mathrm{NaOH}$ solution. Prior to its measurement in a high-precision proportional system, the liberated $\mathrm{CO}_{2}$ gas was purified over charcoal. The standard deviation of a single ${ }^{14} \mathrm{C}$ measurement using this method is $\sigma= \pm 0.17 \mathrm{mBqm}^{-3}$. When determining ${ }^{14} \mathrm{C}$ concentration in air, this uncertainty tends to be higher and may reach $0.5 \mathrm{mBqm}^{-3}$ due to the uncertainties of the sampling.

Most of the samples were measured by liquid scintillation counting (LSC), after precipitation of $\mathrm{CO}_{2}$ in the form of $\mathrm{BaCO}_{3}, 4 \mathrm{~g}$ of which was mixed with $0.8 \mathrm{~g} \mathrm{Cab}-\mathrm{O}-\mathrm{Sil}^{5}$ and 20 -ml toluene-based LS cocktail. The typical sensitivity of this LSC activity measurement was $10 \mathrm{mBqm}^{-3}$.

We determined the mass of the sampled air by weighing the mass of the barium carbonate, or by measuring the volume of $\mathrm{CO}_{2}$ obtained after acid evolution. The sampling period was 2 weeks for stack monitoring and 4 weeks for environmental sampling. The flow rate of sampling was stabilized ca. $10 \mathrm{~L} \mathrm{~h}^{-1}$. The discrimination factor between the ${ }^{14} \mathrm{CO}_{2}$ and ${ }^{14} \mathrm{C}_{\mathrm{n}} \mathrm{H}_{\mathrm{m}}$ fractions was close to 100 , and the absorption of $\mathrm{CO}_{2}$ in the $3 \mathrm{M} \mathrm{NaOH}$ solution was $99.9 \%$ when using a specially designed bubbler-type trap. The conversion efficiency of hydrocarbons into $\mathrm{CO}_{2}$ exceeded $99.7 \%$. Uchrin and Hertelendi (1992) give a detailed description of the sampling devices.

Two differential ${ }^{14} \mathrm{C}$ samplers were installed in the ventilation stacks of the NPP, and five samplers were used in the vicinity of the Paks NPP. Cation and anion exchange resins were separated and then oxidized with $\mathrm{CuO}$. We mixed $4 \mathrm{mg}$ of resin samples with $3 \mathrm{~g} \mathrm{CuO}$, and we kept the gas ampules at $550^{\circ} \mathrm{C}$ for two days, after they were evacuated and sealed. A part of the $\mathrm{CO}_{2}$ produced was diluted with inactive $\mathrm{CO}_{2}$ and its activity was measured in the proportional counter. The carbon content of the exchange resin was determined by an elemental analyzer (type NA $1500 \mathrm{NCS}$ ) and the dry weight of the resins was calculated from the volume of $\mathrm{CO}_{2}$ evolved.

Gas samples from the primary coolant were collected by degassing $75 \mathrm{ml}$ water, and the evolved gases absorbed on activated charcoal kept at liquid nitrogen temperature. After gas chromatographic separation, the ${ }^{14} \mathrm{C}$ activity of hydrocarbons was determined by proportional counting.

${ }^{5} \mathrm{Cab}-\mathrm{O}-\mathrm{Sil}^{\otimes}$, Packard Instrument Co., Ulgersmaweg 47, NL-9731 BK Groningen, The Netherlands 


\section{RESULTS AND DISCUSSION}

Routine ${ }^{14} \mathrm{C}$ sampling of discharged air at the Paks NPP began in 1988. The two ventilation stacks, each of which carried the effluents from a twin reactor unit, were equipped with the sampling systems. The air throughput of each stack was $5.5 \times 10^{5} \mathrm{~m}^{3} \mathrm{~h}^{-1}$. Figures 1 and 2 show the emission data based on a biweekly sampling period for reactor units $1-2$ and $3-4 .{ }^{14} \mathrm{CO}_{2}$ concentration of the discharged air varied in the range of $5-10 \mathrm{Bqm}^{-3}$ with some exceptions when lower $\left(1-2 \mathrm{Bqm}^{-3}\right)$ or higher $\left(15-22 \mathrm{Bqm}^{-3}\right)$ values were observed. Higher concentrations were measured mainly just after the reactor shutdowns. (A similar ${ }^{14} \mathrm{CO}_{2}$ discharge pattern was registered for both stacks.) The same tendency was observed for hydrocarbon emission. It is clear that the ${ }^{14} \mathrm{C}$ released is mainly in hydrocarbon form with concentrations varying between 80 and $200 \mathrm{Bqm}^{-3}$.

\section{1-2 block $1988-1994$}

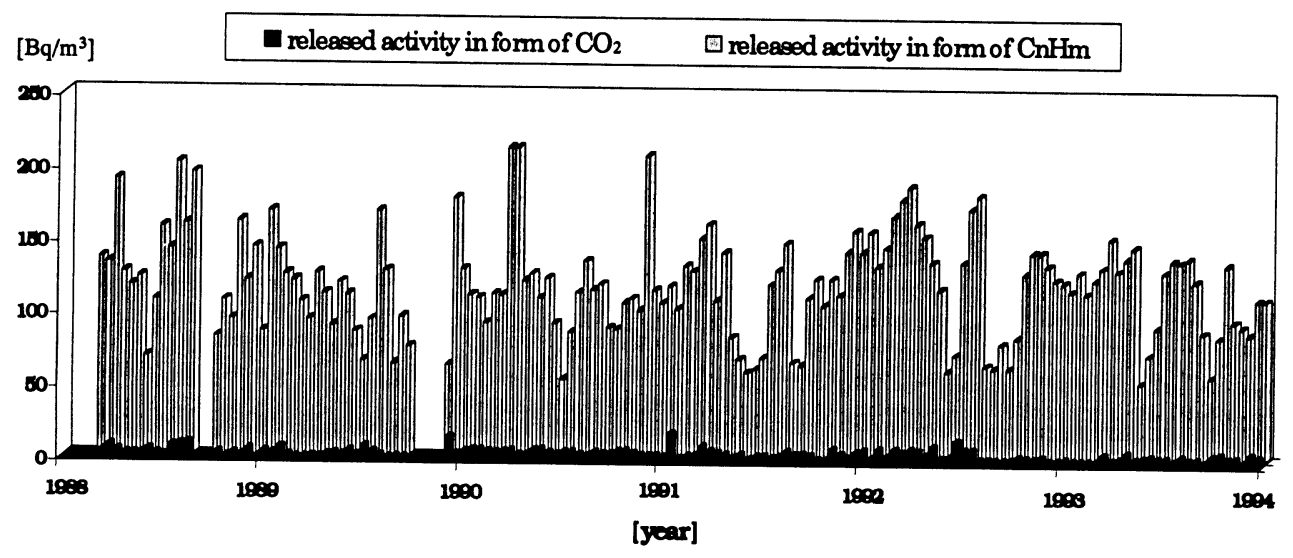

Fig. 1. 1988-1994 biweekly average ${ }^{14} \mathrm{C}$ concentrations of discharge air in ${ }^{14} \mathrm{CO}_{2}(\square)$ and ${ }^{14} \mathrm{C}_{\mathrm{n}} \mathrm{H}_{\mathrm{m}}($ ( $/$ ) chemical forms (block 1-2)

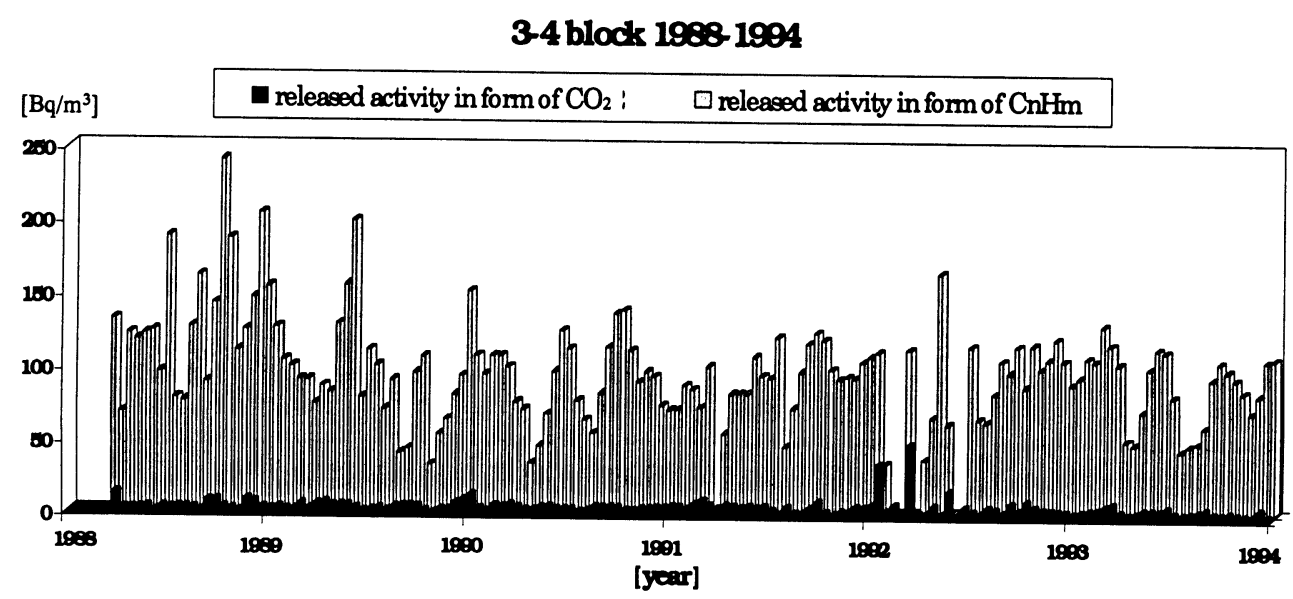

Fig. 2. Biweekly average ${ }^{14} \mathrm{C}$ concentrations of discharge air in ${ }^{14} \mathrm{CO}_{2}(\square)$ and ${ }^{14} \mathrm{C}_{\mathrm{n}} \mathrm{H}_{\mathrm{m}}($ ( $)$ ) chemical forms (block 3-4) 
The ${ }^{14} \mathrm{C}$ discharge data are summarized in Table 1 and illustrated in Figure 3 . The normalized total ${ }^{14} \mathrm{C}$ release was $0.80 \mathrm{TBqGW}_{\mathrm{e}}^{-1} \mathrm{y}^{-1} ; 94 \%$ of the total ${ }^{14} \mathrm{C}$ discharge was apportioned to hydrocarbons and the remaining fraction, $6 \%$, to $\mathrm{CO}_{2}$. The chemical composition of ${ }^{14} \mathrm{C}$ compounds in effluent gas at Paks NPP agrees well with other published data (Kunz 1985; Uchrin et al. 1993).
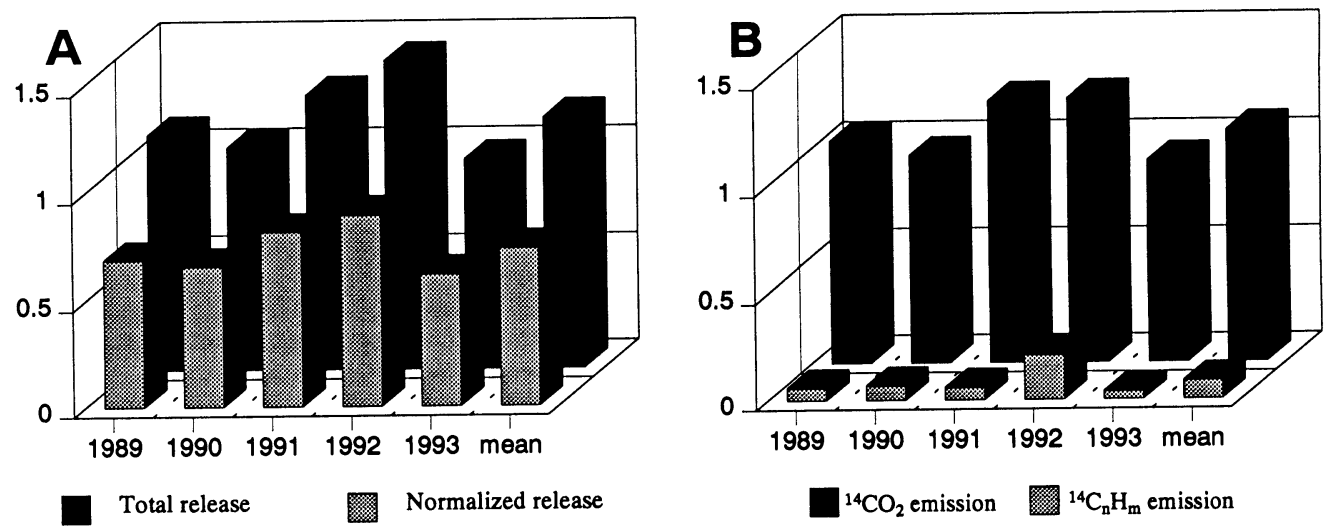

Fig. 3. Summary of data on ${ }^{14} \mathrm{C}$ gaseous effluents at Paks NPP. Normalized release $(A)=T B q G W_{e}{ }^{-1} y^{-1}$; other values $=T B q$

TABLE 1. Summarized Data of ${ }^{14} \mathrm{C}$ Gaseous Effluent Releases at Paks NPP

\begin{tabular}{ccccc}
\hline Year & $\begin{array}{c}\text { Released }{ }^{14} \mathrm{CO}_{2} \\
\text { activity } \\
(\mathrm{TBq})\end{array}$ & $\begin{array}{c}\text { Released }{ }^{14} \mathrm{C}_{\mathrm{n}} \mathrm{H}_{\mathrm{m}} \\
\text { activity } \\
(\mathrm{TBq})\end{array}$ & $\begin{array}{c}\text { Total released }{ }^{14} \mathrm{C} \\
\text { activity } \\
(\mathrm{TBq})\end{array}$ & $\begin{array}{c}\text { Normalized } \\
\text { release } \\
\left(\mathrm{TBqGW}_{\mathrm{e}}{ }^{-1} \mathrm{y}^{-1}\right)\end{array}$ \\
\hline 1989 & 0.06 & 1.04 & 1.10 & 0.69 \\
1990 & 0.07 & 0.97 & 1.04 & 0.66 \\
1991 & 0.06 & 1.22 & 1.28 & 0.82 \\
1992 & 0.21 & 1.23 & 1.44 & 0.90 \\
1993 & 0.04 & 0.94 & 0.98 & 0.62 \\
\hline
\end{tabular}

Results of these measurements indicate that the ${ }^{14} \mathrm{C}$ activities released are distinctly higher than the European average, $0.22 \mathrm{TBqGW}_{\mathrm{e}}^{-1} \mathrm{y}^{-1}$ (UNSCEAR 1982) or $0.35 \mathrm{TBqGW}_{\mathrm{e}}^{-1} \mathrm{y}^{-1}$ and 0.12 $\mathrm{TBqGW}_{\mathrm{e}}^{-1} \mathrm{y}^{-1}$ for time periods $1980-1984$ and $1985-1989$, respectively (UNSCEAR 1993). A possible explanation for the observed difference is that the WWER-type PWR uses nitrogen-containing chemicals, ammonium hydroxide $\left(\mathrm{NH}_{4} \mathrm{OH}\right)$ and hydrazine $\left(\mathrm{N}_{2} \mathrm{H}_{4}\right)$ for the regulation of the chemical condition of the coolant. At Paks, the $\mathrm{NH}_{4} \mathrm{OH}$ concentration is kept on average at $50 \mathrm{ppm}$. To determine the source of the enhanced ${ }^{14} \mathrm{C}$ production, we analyzed the dissolved gases in the primary water. Results show that the most important components are hydrogen and nitrogen. The concentrations of $\mathrm{C}_{\mathrm{n}} \mathrm{H}_{\mathrm{m}}, \mathrm{CO}$ and $\mathrm{CO}_{2}$ are not $>1 \%$. The amount of dissolved gas in the primary water varied between 100 and $150 \mathrm{ml}$ liter ${ }^{-1}$. The ${ }^{14} \mathrm{C}$ activity of dissolved gases in the primary coolant was also measured. Preliminary results show that the ${ }^{14} \mathrm{C}$ is in the form of hydrocarbons and its concentration is $c a .4 \mathrm{kBq}$ liter ${ }^{-1}$ water.

We also measured excess ${ }^{14} \mathrm{C}$ in the vicinity of the Paks NPP by sampling environmental air. The sampling sites A1, A4, A6 and A8 were equipped with similar samplers to those used in the stack. They are $c a .2 \mathrm{~km}$ from the $100-\mathrm{m}$-high stack. For reference, a sampler was operated at station B24 ca. $20 \mathrm{~km}$ from the NPP. Continuous sampling was started in 1989 at station A8, and since 1992, 
monthly air samples have been taken at four stations around the NPP. Figure 4 shows $\mathrm{D}^{14} \mathrm{C}$ data. The long-term average excess due to the NPP corresponded to $\mathrm{D}^{14} \mathrm{C}=3.5 \%$ for $\mathrm{CO}_{2}$ and $\mathrm{D}^{14} \mathrm{C}=20 \% 0$ for hydrocarbon forms.

We determined the ${ }^{14} \mathrm{C}$ concentrations in ion exchange resin used for the reactor water purification system of Paks NPP. A mixture of VARION KS-N cation type $\left(\mathrm{SO}_{3}-\mathrm{CNH}_{3}-\mathrm{C}_{6} \mathrm{H}_{6}-\mathrm{C}_{2} \mathrm{H}_{3}\right)$ and VARION AT-N anion type $\mathrm{BO}_{3}-\left(\mathrm{CH}_{3}\right)_{3} \mathrm{~N}-\mathrm{C}_{6} \mathrm{H}_{6}$ exchange resins are used in the reactor water purification systems. The carbon content of cation and anion exchange resin is $47.5 \%$ and $55.1 \%$ of dry weight, respectively. The ${ }^{14} \mathrm{C}$ activities of spent mixed-bed ion exchange resins vary from 1.2 to $5.4 \mathrm{MBqkg}^{-1}$ of dry weight for all reactor units investigated. The results are summarized in Table 2.

TABLE $2 .{ }^{14} \mathrm{C}$ Activity in Mixed Bed Ion Exchange Resins Used For Purification of the Reactor Water in Paks NPP

\begin{tabular}{llc}
\hline Sample code & $\begin{array}{c}\text { Date } \\
\text { (day. mo. yr) }\end{array}$ & $\begin{array}{c}\text { Activity } \\
(\text { dry weight) } \\
\left(\mathrm{kBqkg}^{-1}\right)\end{array}$ \\
\hline 1. Block 1 0TE 01 (upper) & 05.05 .1991 & 2585 \\
1. Block 1 0TE 01 (middle) & 05. 05. 1991 & 1247 \\
1. Block 1 0TE 01 (lower) & 05.05 .1991 & 1609 \\
2. Block 2 0TE 01 (upper) & 01.09 .1990 & 5395 \\
2. Block 2 0TE 01 (middle) & 01.09 .1990 & 3791 \\
2. Block 2 0TE 01 (lower) & 01.09 .1990 & 3260 \\
3. Block 3 0TE 01 (upper) & 22.07 .1989 & 4085 \\
3. Block 3 0TE 01 (middle) & 22.07 .1989 & 4078 \\
3. Block 3 0TE 01 (lower) & 22.07 .1989 & 3760 \\
4. Block 4 0TE 01 (upper) & 01.03 .1990 & 1793 \\
4. Block 4 0TE 01 (middle) & 01.03 .1990 & 2568 \\
\hline
\end{tabular}

${ }^{14} \mathrm{C}$ release into the environment has both local and global radiological impacts. The dose contribution due to elevated ${ }^{14} \mathrm{C}$ concentrations in the vicinity of a NPP is on the order of $1 \mu \mathrm{Svy}^{-1}$, depending on the type and capacity of the reactor (Levin et al. 1988). For PWR-type NPPs, where the ${ }^{14} \mathrm{CO}_{2}$ is only a minor fraction of the total discharge, the effective dose equivalent to individuals is negligible. The calculated maximum effective dose equivalent for the Paks NPP is $30 \mathrm{nSvy}^{-1}$ if only the ${ }^{14} \mathrm{CO}_{2}$ form is considered, and $0.6 \mu \mathrm{Svy}^{-1}$ when the hydrocarbons are accounted for (conservative estimate). It is estimated that by the year 2050 , the individual dose due to reactor-derived ${ }^{14} \mathrm{C}$ will reach 1.8 $\mu \mathrm{Svy}^{-1}$, which is $12 \%$ of the total dose of $15 \mu \mathrm{Svy}^{-1}$ attributed to natural ${ }^{14} \mathrm{C}$ (McCartney, Baxter and Scott 1988a, 1988b).

The estimated total release of ${ }^{14} \mathrm{C}$ from all nuclear power operations up to 1990 is $c a .9 \times 10^{15} \mathrm{~Bq}$ (NCRP 1985), yielding a dose rate of $180 \mathrm{nSvy}^{-1}$. This value is $c a .1 .5 \%$ of the dose from natural ${ }^{14} \mathrm{C}$, which amounts to only $1 \%$ of the total dose equivalent from natural background radiation.

The long-term effects of ${ }^{14} \mathrm{C}$ discharges are estimated on the basis of collective effective dose equivalent commitment (CEDEC) from a nominal unit release $(1 \mathrm{TBq})$ of ${ }^{14} \mathrm{C}$ from the nuclear industry. The UNSCEAR (1993) report gives a range between 67 and 59 man-Sv per TBq for collective effective dose per unit release. In our calculation, a conservative value of 41 man-Sv per TBq (McCartney, Baxter and Scott 1988a, 1988b) was used. The CEDEC due to ${ }^{14} \mathrm{C}$ release from the Paks NPP is calculated to be $170 \mathrm{man}-\mathrm{Sv}$ for the year 1993, and $1480 \mathrm{man}-\mathrm{Sv}$ based on the total period of the NPP's operation, 1983-1993. 


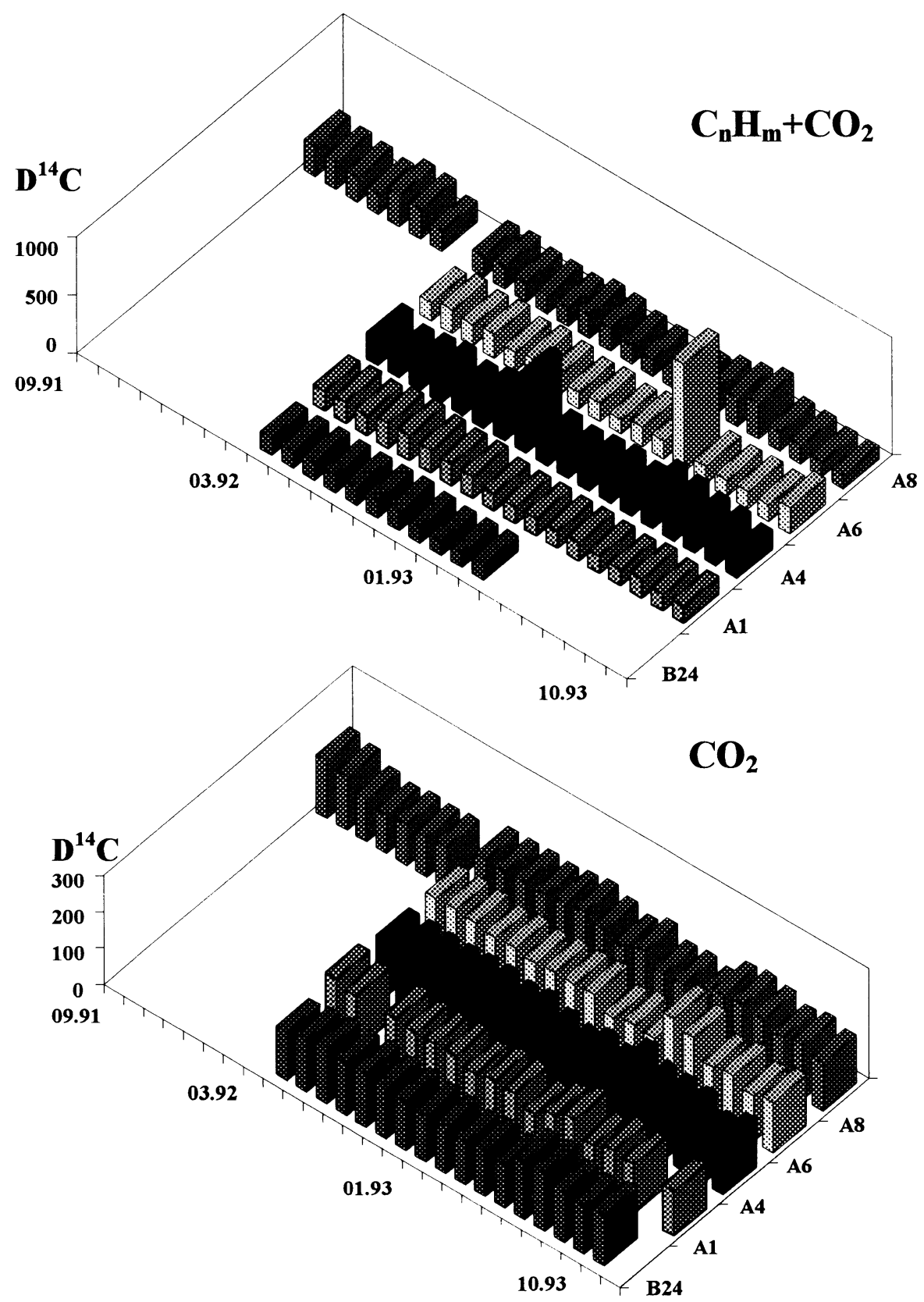

Fig. $4 .{ }^{14} \mathrm{C}$ excess in the environmental air at stations $\mathrm{A} 1, \mathrm{~A} 4, \mathrm{~A} 6$ and $\mathrm{A} 8$ and at the reference station $\mathrm{B} 24$

These collective dose equivalent commitments will be delivered if the sum is taken to infinity and $8 \%$, $24 \%$ and $75 \%$ of the total dose is delivered in 100,1000 and $10,000 \mathrm{yr}$, respectively. We assume that ${ }^{14} \mathrm{C}$ released in a form other than $\mathrm{CO}_{2}$ will be oxidized to this form. For the methane fraction, this is a plausible assumption because its lifetime is $7.5 \mathrm{yr}$ in the environment (Khalil and Rasmussen, 1985). 


\section{Conclusion}

Experience gained from $6 \mathrm{yr}$ of monitoring ${ }^{14} \mathrm{C}$ discharges from the Paks NPP shows that the normalized release rate is $0.8 \mathrm{TBqGW}_{\mathrm{e}}^{-1} \mathrm{y}^{-1}$; this figure is about four times higher than the mean value of Western European PWR ${ }^{14} \mathrm{C}$ discharges. The higher ${ }^{14} \mathrm{C}$ production rate is due to the higher level of nitrogen impurities in the primary coolant. Only $6 \%$ of the ${ }^{14} \mathrm{C}$ activity is apportioned to $\mathrm{CO}_{2}$. This lowers the local radiological impact by a factor of 20 compared with boiling-water reactors, where the release is mainly in the form of $\mathrm{CO}_{2}$. The annual effective dose equivalent to individuals, based on a conservative estimate in the vicinity of the Paks NPP in 1993 due to ${ }^{14} \mathrm{C}$ release, is $<600$ nSv. In general, the local and regional impact of reactor-generated ${ }^{14} \mathrm{C}$ is low compared with ${ }^{14} \mathrm{C}$ of natural origin and from weapon tests. These latter items still amount to $2.5 \mu \mathrm{Svy}^{-1}$, which is more than an order of magnitude greater than that of reactor ${ }^{14} \mathrm{C}$. The global impact of ${ }^{14} \mathrm{C}$ released to the environment is of importance because its collective effective dose equivalent commitment is far higher than the contribution from other global radioactive contaminants.

\section{ACKNOWLEDGMENT}

The authors would like to thank to M. Mogyorósi for her technical help.

\section{REFERENCES}

Davis, W. 1979 Carbon-14 production in reactor. In Carter, M. W., Moghissi, A. A. and Khan, B., eds., Management of Low Level Radioactive Waste 1. Oxford, Pergamon Press: 151-191.

Hertelendi, E., Csongor, E., Záborszky, L., Molnár, J., Gál, J., Györffy, M. and Nagy, S. 1989 A counter system for high-precision ${ }^{14} \mathrm{C}$ dating. In Long, A., Kra, R. S. and Srdoc, D., eds., Proceedings of the 13th International ${ }^{14} \mathrm{C}$ Conference. Radiocarbon 31(3): 399 406.

Hertelendi, E., Uchrin, Gy. and Ormai, P. $1989{ }^{14} \mathrm{C}$ release in various chemical forms with gaseous effluents from the Paks Nuclear Power Plant. In Long, A., Kra, R. S. and Srdox, D., eds., Proceedings of the 13th International ${ }^{14} \mathrm{C}$ Conference. Radiocarbon 31(3): 754 761.

Khalil, M. A. K. and Rasmussen, R. A. 1985 Causes of increasing methane: Depletion of hydroxyl radicals and rise of emission. Atmospheric Environment 19: $397-407$.

Kunz, C. O. 1985 Carbon-14 discharge at three light-water reactors. Health Physics 49: 25-35.

Levin, I., Kromer, B., Barabas, M. and Münnich, K. O. 1988 Environmental distribution and long-term dispersion of reactor $\mathrm{CO}_{2}$ around two German nuclear power plants. Health Physics 54: 149-156.

Loosli, H. H. and Oeschger, H. $1989{ }^{14} \mathrm{C}$ in the environment of Swiss nuclear installations. In Long, A., Kra, R. S. and Srdoc, D., eds., Proceedings of the 13th International ${ }^{14} \mathrm{C}$ Conference. Radiocarbon 31(3): 747753.

McCartney, M., Baxter, M. S., McKay, K. and Scott, E. M. 1986 Global and local effects of ${ }^{14} \mathrm{C}$ discharges from the nuclear fuel cycle. In Stuiver, M. and Kra, R.
S., eds., Proceedings of the 12 th International ${ }^{14} \mathrm{C}$ Conference. Radiocarbon 28(2A): 634-643.

McCartney, M., Baxter, M. S. and Scott, E. M. 1988a Carbon-14 discharges from the nuclear fuel cycle, 1 , Global Effects. Journal of Environmental Radioactivity 8: 143-155.

1988b Carbon-14 discharges from the nuclear fuel cycle, 2, Local Effects. Journal of Environmental Radioactivity 8: 157-171.

Obelic, B., Krajcar-Bronic, I., Srdox, D. and Horvatinčic, N. 1986 Environmental ${ }^{14} \mathrm{C}$ levels around the 632 $\mathrm{MW}_{\mathrm{e}}$ nuclear power plant Krsko in Yugoslavia. In Stuiver, M. and Kra, R. S., eds., Proceedings of the 12th International ${ }^{14} \mathrm{C}$ Conference. Radiocarbon 28(2A): 644-648.

Otlet, R. L., Longley, H. and Walker, A. J. 1989 Studies of environmental radioactivity in Cumbria Part 13: Measurements of carbon-14 in tree-rings from trees growing in the Sellafield area. AERE $R$ 12362, London, HMSO: 24 p.

Otlet, R. L., Walker, A. J. and Fulker, M. J. 1990 Survey of the dispersion of ${ }^{14} \mathrm{C}$ in the vicinity of the UK reprocessing site at Sellafield. Radiocarbon 32(1): 2330.

Otlet, R. L., Walker, A. J. and Longely, H. 1983 The use of the ${ }^{14} \mathrm{C}$ in natural materials to establish the average gaseous dispersion patterns of releases from nuclear installations. In Stuiver, M. and Kra, R. S., eds., Proceedings of the 11 th International ${ }^{14} \mathrm{C}$ Conference. Radiocarbon 25(2): 593-602.

Otlet, R. L., Fulker, M. J. and Walker, A. J. 1992 Environmental impact of atmospheric carbon-14 emissions resulting from the nuclear energy cycle. In Taylor, $R$. E., Long, A. and Kra, R. S., eds., Radiocarbon After 
Four Decades: An Interdisciplinary Perspective. New York, Springer-Verlag: 519-534.

Povinec, P., Chudý, M. and Šivo, A. 1986 Anthropogenic radiocarbon: Past, present and future. In Stuiver, $M$. and Kra, R. S., eds., Proceedings of the 12th International ${ }^{14} \mathrm{C}$ Conference. Radiocarbon 28(2A): 668672.

Rublevskij, V. P. 1987 Atomnyje elektrostancii kak generatori ${ }^{14} \mathrm{C}$ (Nuclear power plants as sources of ${ }^{14} \mathrm{C}$ ). Technicheskij Progress $v$ Atomnoj Promyslenosti, Seria Izotopi v USSR 1/72 (in Russian).

Snellman, M. 1989 Sampling and monitoring of Carbon14 in gaseous effluents from nuclear facilities. Technical Research Centre of Finland, Research Notes 1032.

Stenström, K., Erlandsson, B., Hellborg, R., Håkansson, K., Skog, G. and Wiebert, A. 1993a Development of a method to measure the concentration of ${ }^{14} \mathrm{C}$ in the stack air of nuclear power plants by accelerator mass spectrometry (AMS). Report for project SSI P 625.91, Lund, Sweden: 29 p.

1993b Measurement of the ${ }^{14} \mathrm{C}$ concentration in the stack air of two Swedish nuclear power plants by accelerator mass spectrometry (AMS). A one-year study of a PWR in Ringhals and a BWR in Forsmark. Report for project SSI P 625.91, Lund, Sweden: $26 \mathrm{p}$.
Stenström, K., Erlandsson, B., Hellborg, R., Skog, G. and Wiebert, A. $1995{ }^{14} \mathrm{CO}_{2}$ and total airborne ${ }^{14} \mathrm{C}$ releases from PWR and a BWR at Ringhals Nuclear Power Plant measured with accelerator mass spectrometry. Report for project SSI P 781.93, Lund, Sweden: 8 p.

Uchrin, G., Csaba, E., Hertelendi, E., Ormai, P. and Barnabás, I. $1992{ }^{14} \mathrm{C}$ release from a Soviet-designed pressurized water reactor nuclear power plant. Health Physics 63: 651-655.

Uchrin, G., Csaba, E., Volent, G., Chyly, P., Slavik, O., Miklavzic, U., Kobal, L., Mohar, T., 1993 Carbon-14 measurements at three PWR type nuclear power plants. Austrian-Italian-Hungarian Radiation Protection Symposium, Radiation Protection in Neighbouring Countries in Central Europe. Seibersdorf, Österreicher Verband für Strahlenschutz 1: 11-14.

Uchrin, G. and Hertelendi, E. 1992 Development of a reliable differential Carbon-14 sampler for environmental air and NPP stack monitoring. Final Report of the OMFB contract No. 00193/1991 (in Hungarian).

United Nations Scientific Committee on the Effect of Atomic Radiation (UNSCEAR) 1982 Ionizing Radiation Sources and Biological Effects. New York, United Nations Report 259.

1993 Ionizing Radiation Sources and Biological Effects. New York, United Nations Report 99. 